\title{
Proust som indflydelsesmaskine
}

Den alvidende fortæller døde sammen med Gud. Efter Nietzsche er alt fortolkning, og efter Proust ved enhver forfatter, at han bevæger sig på sand. Fortællingen iscenesættes i fortællerens synsvinkel, og synsvinklen indebærer sit eget drama mellem viden og uvished, mellem bevidsthedens grænser og dens fors $\varnothing \mathrm{g}$ på at overskride dem. Jens Christian Grøndahl: Den sibiriske måne

Det er ganske begrænset, hvad der er skrevet om receptionen af Proust herhjemme. Gennem de seneste 100 år er Prousts roman blevet endevendt, beskrevet, vurderet, forkastet og hyldet i ét væk, men der er hverken forsket i det eller formidlingsmæssigt taget bestik af indsatsen. Det konstaterer jeg på baggrund af at have undersøgt emnet gennem mange år. ${ }^{I}$ En lang række litterater, forskere, kritikere, anmeldere, digtere, forfattere og kunstnere fra Christian Rimestad over Thorkild Hansen til Lars von Trier har været optaget af På sporet af den tabte tid, og flere har været direkte inspireret og under Prousts indflydelse, hvilket næppe kan undre. Mest interessant er, at flere af forfatterne i den sidstnævnte kategori, som har været under Prousts indflydelse, eksempelvis Peer Hultberg, Kirsten Thorup og Jens Christian Grøndahl, bryder med det billede af værket som en selvbiografisk erindringsroman, man traditionelt har haft herhjemme. Deres værker skaber ikke alene nye billeder af, hvad det er for et værk, Proust har skrevet. De afspejler også en skrivende (selv) bevidstgørelse om, hvori indflydelsen faktisk består, samt på hvilke måder de selv kan tage den instrumentelt i anvendelse via deres egen fiktion. Det vil jeg vende tilbage til med Grøndahl som eksempel.

Den danske Proust-reception er undergået markante forandringer fra 1914 til 2015. I begyndelsen fokuserede man i betydelig grad og nærmest udelukkende på 
Prousts roman som en biografisk og psykologisk erindringsroman. Først hen imod 1950'erne og i det følgende tiår fik man for alvor øjnene op for værket som moderne og modernistisk nyskabende, hvilket siden suppleredes med opfattelser af romanen som både multifacetteret, polyfon, monstrøs og fuldendt ufuldendt. Opfattelsen af værket som monstrøst kendes fra Frederik Tygstrups refleksioner over romanens form. Romanen som fuldendt ufuldendt findes både i Hans Boll-Johansens og Henning Goldbæks syn på Proust. Den polyfone indstilling spores ligeledes i Niels Egebaks og senere i Jørgen Bruhns forhold til På sporet.

I disse år problematiseres den rent biografiske opfattelse af På sporet af den tabte tid i langt højere grad end tidligere. De sidste tiårs forskelligartede intensive undersøgelser af forholdet mellem læseren og værket har affødt erkendelser af, at Prousts værk bør læses med et langt mere differentieret og opmærksomt blik for romanens forskellige dimensioner. Det sker ud fra en opfattelse af, at værkets mange lag ikke lader sig reducere til hinanden, at de er samtidigt eksisterende. Nyere aktualisering af autobiografiske aspekter, diverse former for fiktive selvfremstillinger og den genre- og virkelighedsproblematiserende bølge, Karl Ove Knausgårds Min kamp førte med sig, har desuden medvirket til at bringe Proust og På sporet i fokus i de skandinaviske lande. Flere og flere forskellige tilgrænsende tilgange til Proust har budt sig til, der dog hverken kan forklare eller rumme hinanden, og de står i dag side om side. Det gælder også forsøg som dette, på at præcisere, hvordan Prousts værk gør sin indflydelse gældende. Sagt i al korthed har billedet og opfattelsen af Proust og hans roman åbnet sig i bredden og dybden i retning af det stadig mere uoverskuelige.

Lad os pejle os nærmere ind på receptionen. I perioden 1930-1950 læste man efter tur værket biografisk, autobiografisk og åndshistorisk. Som følge af den franske tematiske kritiks indtog i 1960'erne med Georges Poulets og René Richards fokusering på værket og skriften, ændredes opfattelsen af Prousts roman betydeligt. En tendens, som yderligere forstærkedes af Claude Simons, Michel Butors, Nathalie Sarrautes og Alain Robbe-Grillets forskelligartede udformning af le nouveau roman (den nye roman). Sidstnævnte, som blev talsmand for den litterære bølge, skrev: "Siden Proust og Faulkner forekommer tilbageblikkene til fortiden, bruddene i kronologien at være en del af selve grundlaget for fremstillingens opbygning." Det litterære værk skulle ligesom filmen være en "refleksion over den menneskelige erindring, dens usikkerheder, dens stædighed, dens dramaer osv." (Robbe-Grillet 1965, 141). Til disse perspektiver skal føjes Gilles Deleuzes frugtbare ændring i opfattelse af Prousts værk med påpegningen af, at På sporet ikke vender sig mod fortiden, men fremtiden. Gérard Genettes narrative teori, der udvikledes ud fra Prousts værk, og Roland Barthes' aflivning af forfatteren banede vej for en på én gang mere tekstfunderet og mere specifik tilgang, hvor man som modtager spillede aktivt ind med sin skabende/skrivende læsning.

Den strukturalistiske tænkning og analysepraksis bragte kort sagt værket og dets strukturer på dagsordenen. Den betydelige værkorientering fulgtes snart op af en mere fri og uortodoks tilgang til Prousts værk som et felt af praksisser, blikke og indbyrdes diskuterende poetikker. Dette kan på bemærkelsesværdig vis ses i forhold til, at der herhjemme fra 1995 og frem indtraf et mindre paradigmeskifte. Det var 
Proust-temanummeret af Ny Poetik i 1995 eksponent for. Da blev flere af 1960'ernes teoridannelser, herunder strukturalistiske optikker, aktualiseret, hvilket betød, at der én gang for alle blev gjort op med enhver entydig tilgang til Proust og hans værk. Temanummeret samlede ikke blot op på teoretiske indstillinger i forhold til Proust. På sporet blev også nybelyst på principiel vis via detaljeanalyser. Konsekvensen var, at man pludselig stod med en hel buket af samtidige forskelligartede tilgange til det proustske værk, hvor teoretiske anskuelser i flere tilfælde virkede anskueliggørende ind på biografiske og vice versa. Proust-receptionen var med andre ord blevet til et åbent udvekslingsfelt mellem samtidigt eksisterende tilgange, en åbenhed, der svarer glimrende til værkets egen sammensatte konstruktion.

Set i historisk perspektiv finder jeg derfor grund til at understrege, at der er indtruffet så markante forandringer i forholdet mellem forfatter og værk, mellem værk og læser, mellem Proust som værk og os, mellem Proust og os, at vi bør gen- og nybesinde os på litteraturreceptionens rolle, og hvad det vil sige at læse og tage bestik af læsning i en historisk kontekst. Det skal ikke glemmes, at en forfatter som Proust, i og med sine vidtrækkende romanrefleksioner over læsning, hvad læsning gør og betyder, selv foregreb såvel receptionsaspekter som flere af de opfattelser af læsning, der gør sig gældende i dag. Det gælder ikke mindst opfattelsen af læserens afgørende aktive rolle som den, der i sidste instans bringer værket til fuldendelse gennem sin (med)skabende tolkning. Jeg tænker her også på mindre animerede forsøg på at bringe Proust og hans værk ud i forhold til en større og bredere forståelseshorisont, end der tidligere har været tradition for i Danmark. Set i receptionsperspektiv kan selv den mest kortfattede danske analyse af Prousts værk have stor indvirkning på forståelsen af værket. Det er talrige bidrag i Det danske Proust-selskabs årlige Bulletin, værdige eksempler på. De får også betydning fremefter.

Betragtet under ét tegner der sig et stadig tydeligere billede af På sporet som et uhåndterligt fascinerende og konstant problematiserende gespenst; en sitrende perspektivbank og en monstrøs indflydelsesmaskine, der er både en skræmmende anfægtelse og katalytisk instans for flere og flere danske forfattere. Der er imidlertid stadig en betydelig tendens til, at man ikke vil besnakkes eller overtales/overtages af Proust. Respekten for hans roman fører så langt som til en afstandstagen, selv hos forfattere, der ikke har læst en linje af ham. Det var en tidlig, kvalificeret indvending fra Jørgen Gustava Brandt, der skarpt kritiserede den danske kulturelle offentligheds falske forhold til Proust: Man foregav at have læst hans værk uden så meget som at have åbnet det. Han mente således, at der lå både komplekser, afmagt og stor uvidenhed til grund for de fordomme, man omgav sig med vedrørende Prousts værk, som altså på sin side forblev et helt andet, end danske læsere generelt gad at opnå kendskab til.

Sideløbende med at opspore betydelige påvirkninger, finder man også modgående tendenser i den danske kulturelle offentligheds forhold til Proust. Under ét kan man om den danske litteratur og kultur fra Christian Rimestad og Thorkild Hansen til Jens Christian Grøndahl, Josefine Klougart og Lars von Trier konstatere, at den har medvirket til at ændre opfattelsen af Prousts roman, eftersom påvirkningen og indflydelsen fra Proust også har virket - og til stadighed virker - tilbage på opfattelsen af det værk, han selv blev forvandlet til. Der er tale om en trafik, der 
fører begge veje, hvor påvirkning og indflydelse indvirker generativt på hinanden og fornyer Proust-forståelsen herhjemme.

Af danske litterater og forfattere, der mere eller mindre eksplicit har haft en slags afhængighedsforhold til Proust og hans roman eller været inspireret af samme, kan nævnes: Henrik Bjelke, Suzanne Brøgger, Steen Bach Christensen, Vibeke Grønfeldt, Jørgen Gustava Brandt, Anne Kirstine Chaplin Hansen, Thorkild Hansen, Lise Nørgaard, Josephine Klougart, Margrete Møller, Jacob Paludan og Kirsten Thorup. $^{2}$

Der findes givetvis en del andre danske digtere og forfattere, der har nippet til den franske forfatter, eller som i skjul bag deres mere eller mindre udadvendte eller flersidige praksis går til og fra ham lige så ordpropmætte og indtrykstilstoppede som inspirerede. Det er tydeligvis kendetegnende for en digter som Klaus Høeck. Hans relation til På sporet er et bemærkelsesværdigt eksempel på, hvordan en digters skeptiske Proust-reception på produktiv vis kan udfordre vores indstilling til den franske forfatter og løfte hans roman frem i et kritisk lys: "Prousts fors $\varnothing \mathrm{g}$ på at fange tiden gennem en skabende erindringsproces og en helheds-konstruktion er filosofisk set komplet umulig. Tiden kan ikke fanges og jeget kan ikke komme ind i sit eget kunstværk." (Høeck 2012, 114). Det betyder ikke, at Høeck forkaster Proust.

Modstanden virker tværtimod motiverende ind på hans stadige hug-læsende indstilling til værket, hvor en springende, tilfældig læsning provokerer tanker og indsigter frem. Et ganske andet eksempel på modstand spores i Thorkild Hansens yderst ambivalente forhold til Proust. ${ }^{3}$

Set fra litteraturhistorisk hold har receptionsæstetikkens udformning i Tyskland også bidraget til åbninger i forståelser af Prousts værk fra en udbredt optagethed af værket/teksten selv som en lukket eller sluttet æstetisk form til at betone værket som et åbent felt, en mangetydig betydningsbank og perspektivmaskine. Det er ikke mindst forårsaget af to forhold: dels den tiltagende teoretiske opmærksomhed på læsningens rolle og læserens reaktioner i forhold til værket, dels den betydelige bachtinske orientering i forhold til romanen, der har affødt en mere flertydig forståelse af det litterære værk som polyfont, som bestående af mange forskellige stemmer, der tilsammen lader forfatteren komme til orde, hvilket i sig selv afkræver en særlig indstilling hos læseren.

Med andre ord har den strukturalistiske og semiotiske litteraturvidenskab haft en væsentlig indvirkning på forholdet til det enkelte litterære værk. Den læserinvolverende tilgang og polyfone udfordring har bidraget til det paradigmeskifte, der er indtruffet. Det gælder ikke mindst i forhold til receptionens rolle, herunder den indflydelse, det litterære værk udøver.

\section{Litteraturreception og læsning}

Lad os derfor rekapitulere i forhold til litteraturreceptionen. Betegnelser som 'receptionshistorie' og 'receptionsteori' er udtryk for en litteraturhistorisk retning, der fokuserer på læserens rolle i fortolkningen af tekster. For receptionsteoretikeren er læseren en dynamisk aktør, der via sine reaktioner bringer den læste tekst i dialog med andre tekster. Det er dette, samt læserens æstetiske erfaring, som Hans Robert 
Jauss rettede sin opmærksomhed imod, da han i 1960'erne udviklede sit receptionsbegreb, som blev formet til en egentlig receptionsæstetik i 1970'erne under påvirkning fra tysk hermeneutik.

Jauss betoner læserens modtagelse af et værk, der lader sig aflæse via købstal og oversættelser, samt i litteraturkritikken i form af anmeldelser eller læserreaktioner, private breve mv. Han karakteriserer virkningsforholdet på to måder, dels hvordan værkerne forholder sig til hinanden, dels hvordan det påvirker læserne og modtagerne, så de når frem til en ny forståelse af sig selv. Han skriver f.eks.:

det autentiske nye værk [reviderer ikke blot] vort syn på det tidligere værk. Her skal også det tidligere værk medregnes, som bærer skin af det uforgængeligt skønne og - ifølge Malraux - kropsliggør kunsten som modskæbne [Gegen-Schicksal], forståelsens produktive arbejde for at rykkes ud af det imaginære museum og åbnes for vor samtids betydningshorisont. Og her kan til sidst også nedfældningen af kunstens historie genvinde sin omstridte berettigelse, når den udforsker og beskriver værkets kanon og sammenhæng, forynger den menneskelige erfaring der tidligere lå gemt i kunstens skatte og samtidig gør den tilgængelig for vor samtidige forståelse. (Jauss 1992, 396).

I dette citat ligger indflydelsesaspektet indfoldet som en potentiel indsigtsgivende faktor, hvor hele processen fra modtagelsen til aflæsningen af indflydelse rummes under én og samme overordnede betegnelse: reception. Kort sagt handler litterær indflydelse om forskellige genrer, virkefelter og praksisser. Litterær modtagelse vedrører derimod praksisser, der introducerer og overfører værker til den litterære offentlighed. Litterær indflydelse er ensbetydende med de "interne" aktiviteter mellem forfattere, der skaber nye litterære værker. ${ }^{4}$ At jeg gør opmærksom på dette, skyldes det forhold, at Jauss opererer med termerne 'modtagelse' og 'indflydelse' på lige fod som uadskillelige og lige nødvendige, men uden at han gør brug af begrebet "indflydelse". For Jauss var reception ensbetydende med en afbalancerende vægtning og accentuering, hvor indflydelse og modtagelse indgår som to ligestillede polære værdier.

Jeg sporer et spektakulært spændingsfelt mellem modtagelsen af og indflydelsen fra På sporet af den tabte tid. Der er indsigter og forskningsmæssige aspekter at hente på begge sider, som vil kunne tilføre den samlede forståelse af Prousts værks indflydelse fornyende perspektiver, der forsyner værket med et ganske andet liv, end man først antog det havde. Det være sig som en kanonisk anstødssten (på modtagelsessiden) og som en betydningsmæssig indvirkningsgenerator (på indflydelsessiden), man aldrig vil kunne sætte definitive grænser for. Prousts På sporet er, således betragtet, ikke så lidt af en indflydelsesmaskine, hvilket forfatteren Jens Christian Grøndahl fik indsigt i og siden tog den digteriske konsekvens af.

Grøndahl var stærkt inspireret af le nouveau roman, i særdeleshed Claude Simon. De tidlige romaner blev således skrevet i en snørklet, stram og abstrakt prosa, hvilket hurtigt stemplede ham som en smal forfatter. Det var nærmere bestemt under sin første læsning af Proust som 30-årig i Spanien, hvor han opholdt sig et halvt år for at skrive på sin tredje eksperimenterende roman og netop var under indflydelse af "den nye roman", at Grøndahl tog afsked med avantgarden - uden at vide 
det. Han indså, at "ambitionen om at drive sproget ud af traditionen for at møde virkeligheden mere åbent, mere uhildet og nøgent” (Grøndahl 2010, 99), var en blindgyde. Den erkendelse fik han senere Proust at takke for, som det vil fremgå i det følgende. Der skulle en resolut stilistisk omkalfatring til, før han nåede ud til et større publikum. Han ønskede ikke at blive offer for den sprogkonflikt, han selv stilistisk gang på gang ekspliciterede. Han ønskede at udtrykke sig med en mere traditionelt fortællende stemme:

4 Det var en lettelse, da jeg overgav mig til en mere klassisk stil og i samme åndedrag opdagede, at man godt kan skildre følelsernes kaos og al menings flygtighed uden at skrive kaotisk eller uforståeligt. Det var et afkald på at "bryde med det gamle" og en afsked med den forfængelige drøm om originalitet, men det var også en genvej til at blive netop den forfatter, netop jeg kan være. (Ibid.)

Bekræftelsen på, at målet var nået, kom med kærlighedsromanen Lucca (1998), der blev hans gennembrud til et større publikum, som han aldrig siden har mistet. Tværtimod. Det er med årene taget betragteligt til i omfang, efterhånden som han har rendyrket sin traditionelle, almenmenneskeligt og eksistentielt appellerende stil. Fra 1995 indledte Grøndahl med Ved flodens munding (1995) det kritisk-essayistiske spor, som han ikke siden har sluppet.

\section{Skyggen i dit sted}

I hans femte roman, Skyggen i dit sted, 1991, der var det værk, Grøndahl skrev på i Spanien, spores en betydelig Proust-påvirkning, som han ingenlunde forholdt sig passivt til. Han udnyttede den i og med sin egen fiktion, ikke mindst belært af et andet af sine forbilleder, Claude Simon, der på sin egen fiktions præmisser forholdt sig yderst aktivt og eksperimenterende til Prousts indflydelse. Han vedstod sig Prousttekstens evidente betydning og skrev videre for siden at udfordre den fra sin egen skrifts positioner.

For det første indskriver Grøndahl På sporet i sin egen fiktive fortælling ved at lade et af romanens bind med Boye Willumsens tegning på forsiden - fra første bind af syvbindsgenudgivelsen af den første oversættelse fra 1930'erne - figurere som en konkret genstand, eksempelvis på den kvindelige hovedpersons natbord, i Skyggen $i$ dit sted. Fortælleren gør sig flere refleksioner over forsidebilledet.

For det andet citeres der direkte fra Prousts værk, ligesom der optræder scener derfra, eksempelvis med Swann og Odette, der indgår som indirekte anledning til og afsæt for fabuleringer. Ved at forholde sig til På sporet som et intertekstuelt grundlag for sin egen, betydeligt mere brudte, modernistiske fiktion viser Grøndahl både, hvor han er enig og ikke kan komme uden om, og hvor han bryder med Proust. Ligesom han viser tilbage til vores fælles litterære arv og ballast, som vi trækker på i form af myter, hvad enten vi er os det bevidst eller ej.

Hovedtemaerne i Skyggen i dit sted er erindring, tid, ensomhed, rejse og forandring. På realplanet møder man til at begynde med et fortællerjeg, der graver sig gennem sneen med et fejeblad. Det er mørkt. Han er angiveligt i færd med at grave 
sig ind til et tilsneet sommerhus med spindelvæv og insektgifte. Der er i hvert fald tale om et sted, der længe har været forladt. Det er den position, der fortælles fra. Den mandlige fortæller har langt tilbage haft en affære med en gift kvinde, med hvem han blandt andet foretog en rejse til Spanien. En dag møder han tilfældigt kvinden igen på gaden sammen med sin mand, som hun vendte tilbage til, og som fortælleren aldrig tidligere har truffet. Dette møde, der måske højst tager fem minutter, og hvor der blot udveksles et par ord - selve denne genkendelse - er katalysator for fortællerens erindringer, sådan som de opstår og udløser sig i ham, mens han ligger dér og graver.

Fortælleren hjemsøges af en rastløs og ikke nærmere defineret længsel efter at finde en form for kontinuitet i sig selv, hvilket på forhånd imidlertid er dømt til at mislykkes. Det har fortælleren allerede erkendt i fortællende, skrivende stund:

Du nåede hende aldrig helt, tilbagelagde aldrig den sidste afstand, altid efterladt ved siden af hende, mens tog og biler kørte jer gennem byer, skove og bjerge. Du kan ikke se det, det findes ikke mere. Kun her, kun som disse ord. [...] Jeg kan kun fortælle om den afstand, som jeg hvert øjeblik måtte tilbagelægge, hvert af vores øjeblikke, afstanden til hendes ansigt. (Grøndahl 1991, 33-34)

Fortællerens erindringer opløses i fiktive tanker og disparate synsbilleder. Det kan antagelig lade sig gøre at genkende eller gense de jeger, man har været, men det er ikke muligt at komme i nogen egentlig kontakt med dem. Vores bevidsthed er en fiktionsmaskine, der selv producerer et spind af fiktioner, som vi i sagens natur erfarer, er umulige at slippe ud af. Dermed bliver det heller ikke muligt for os at erkende nogen objektiv sandhed. Vi er overladt til en endeløs række af subjektive antagelser. Det er en noget nihilistisk livsanskuelse, der ligger til grund for fortællerens refleksioner, ikke mindst hvis man ser nærmere på, hvordan livsvilkårene tager sig ud i hans optik. Til gengæld må man sige, at man som læser får modspil fra forskellige kanter, når det gælder om at tage stilling til, hvad der er virkelighed, og hvad der er fiktion i Grøndahls roman. Hvornår er vi udelukkende inde i fortællerens bevidsthed? Hvornår er vi i selve det fortalte, løsrevet fra fortælleren? Og hvornår befinder vi os i selve den såkaldte virkelighed med træk og slip og taktile kendsgerninger?

\section{Glemselen, mørket og natten}

I Grøndahls univers er menneskets elementer glemselen, mørket og natten, der på samme tid forener og adskiller. ${ }^{5}$ Fortidens billeder findes spredt omkring som luftblærer i en ismasse. Fortælleren har gennem lang tid glemt og fortrængt affæren med kvinden, han mødte. Gensynet med hende fremstår egentlig ikke som et reelt gensyn, men afføder blot en indirekte konstatering af, at han selv er blevet en anden. Og det er i særlig grad afstanden mellem den, han var dengang, og den, han er nu, romanen handler om, og som fortælleren igen og igen forsøger at udmåle og udgrunde: "Være den, du ikke kendte, blive den fremmede, som du bar i dig, spærret inde bag dit ansigt. Som strakte sit blik ud gennem åbningerne i dit ansigt for at møde hendes, blive genkendt af hendes fremmede øjne" (Grøndahl 1991, 8). 
Sammenfatter man hovedpunkterne i Grøndahls opfattelse af Proust, grundes de især på fremskrivningen af den personlige tid, erobringen - og skriftens evne til af afsætte spor; - af den personlige erfaring, og erkendelsen af bevidsthedens paradoks mellem at være det eneste sted, hvor verden møder os, og at være den afmægtigt blokerende instans, der afskærer os fra verden og dermed fra at overskride den kløft, som adskiller jeget fra verden. Det er derfor, at artiklen indledtes med et citat af Grøndahl, der pointerer, at enhver forfatter fra og med Proust skriver på sand, dvs. underlagt en omfattende, kompleks bevidsthedstragik. Den proustske tragik fra før - implicerer, at ethvert bånd, enhver forbindelse mellem et andet menneske og én selv, kun eksisterer i vor bevidsthed. Når vi af en tilfældig grund holder op med at tænke på denne relation til det andet menneske, eksisterer det ikke mere for os. Det er derfor, at Proust igen og igen giver udtryk for opfattelsen af mennesket som sin egen værste fjende, indespærret som det er i sig selv: "Mennesket er det væsen, som ikke kan komme ud af sin skal, som kun kender andre gennem sig selv, og som ved at sige det modsatte lyver." (Proust 1964/65, bd. 6, 39).

Når Grøndahl inden for sin romans kontekst to gange citerer den samme passus fra På sporet ${ }^{6}{ }^{\text {som }}$ følger herefter, er det af tre grunde. For det første for at udforske og skubbe til jegets grænser. For det andet for at vise, hvorledes mennesket på fatal vis rives med, ja - forføres af sin egen sjæl i en blind tro på, at man alligevel kan nå et andet mennesket, som det er, og møde virkeligheden og tingene i sig selv. Denne sisyfosanstrengelse viser sig også i Grøndahls opbrydning af citatet, der ligeledes markerer forfatterens fors $\varnothing$ g på at overskride det nævnte vilkår i og med skriften. Og for det tredje for at føre en eksistentiel samtale med Proust henover de implicitte afstande mellem hver deres erfaringer. Citatet, Grøndahl benytter sig af, lyder:

if

Thi selv om man altid har fornemmelsen af at være omgivet af sin sjæl, så virker den dog ikke som et ubevægeligt fængsel, det er snarere, som om man rives med af den i en uophørlig anstrengelse for at overskride dens grænser, nå yderverdenen - en anstrengelse, der er dømt til skuffelse. (Ibid., bd. 1, 94)

Oversættelsen er af Christian Rimestad fra 1932. Til sammenligning skyder jeg for en kort stund den danske nyoversættelse af Else Henneberg Pedersen ind. Den forelå godt 70 år senere og er på væsentlige punkter anderledes i og med at 'sjæl' skiftes ud med 'bevidsthed', mens 'uophørlig anstrengelse' erstattes af 'en evig impuls'. Sammenlagt får vi sprogligt med et betydeligt mere tidssvarende udtryk at gøre, der samtidig ikke taber indholdsmæssigt terræn i forhold til, hvad Proust skrev på fransk:

46 For selvom man har en fornemmelsen af altid at være omgivet af sin bevidsthed, er det ikke som i et statisk fængsel, det er snarere som om vi rives med af den i en evig impuls til at prøve at overhale den, nå udenfor, med en slags håbløshed over altid at høre den samme klang, som ikke er et ekko udefra, men genlyden af en vibreren i vores eget indre. (Swanns verden 1,122 ) 
Et sådant eksempel på forskelle mellem den gamle og nye oversættelse findes der et utal af, hvilket bekræfter relevansen af kontinuerligt at bestræbe sig på at nyoversætte et værk som Prousts. Derved vil man sikre en sproglig spændstighed og mulighed for at læse og forstå Prousts værk med en ny tids blik, rundet af oversætterens og den tids åndelige vejrlig.

Den vigtige fortsættelse på Proust-citatet umiddelbart efter lyder:

6 Mens man stadig rundt om sig hører den samme musik, der ikke er et ekko af lyde udefra, men en genklang af strenge, der dirrer i vort indre. Man søger i tingene at genfinde det skær, vor sjæl har kastet over dem, og som har gjort dem dyrebare for os, og man bliver skuffet, når man konstaterer, at de i naturen synes blottede for den fortryllelse, de ejede i vor tanke, ved det nære forhold, hvori de stod til visse ideer. (Ibid.)

Hvorom alting er, bliver konsekvensen for kærlighedens vedkommende - gennem Grøndahls anvendelse af citatet i sin fiktion - en fundamental afstand, en uoverstigelig fremmedhed og en skræmmende udleverethed til glemselen, selvforglemmelsen, tidsophævelsen, regressionen, natten og mørket. Mørket forbinder alle nætter, som værkets essens og det eneste, der skaber kontinuitet. Det er eksempelvis mørket, der gør det umuligt at skelne mellem de to mænd; ægtemanden og jeget, der væves sammen i en fiktion (Grøndahl 1991, 135). Nattemørket er således ikke alene fremmedhedens zone, det er selve udvekslingsstedet for den anonyme, sprogløse kærlighed. Det er dét vilkår, mennesket er underlagt, og som fortælleren erkender til slut i romanen: "Han forstår lidt efter lidt, at han aldrig vil komme tættere på hende end dér i mørket om natten, hvor han ikke kan se hendes ansigt. At det, som hun er, altid vil være noget andet end det, der kan siges eller ses" (ibid., 136).

Den nihilistiske opfattelse, der her kommer til udtryk, bliver ikke mindre dyster og håbløs, når det gælder forsøget på at definere, hvad kærlighed overhovedet er. Det fremgår tydeligvis af fortællerjegets forestillinger om, hvad kvindens mand undervejs i flyet forestiller sig desangående:

14 Måske tænker han, at ordet "kærlighed" betegner en tilstand, som han aldrig vil være i stand til at vurdere og genkende, enten fordi han befinder sig midt i den og derfor ikke kan bestemme dens konturer, dens grænser, dens opståen, dens ophør, eller også fordi han aldrig har befundet sig i den og derfor heller ikke véd, hvad han skal kende den på. (Ibid., 86)

Denne opfattelse er analog med Prousts. Hvor man hos Grøndahl finder kærligheden elimineret til en afstumpet tro på menneskets kropslighed, hvor kroppene i nattens, mørkets, tavshedens og glemselens fælles element lever deres egne liv uafhængigt af dens forsnævrede bevidsthed, er der hos Proust (heller) ingen tro på hverken den åndelige eller den kropslige kærlighed. Alt hvad der er, er en hjælpeløs egoistisk liderlighed - og kan den ikke stilles eller får den sin vilje, tager jalousien over og stilles i besiddelsessygens tjeneste. Der er til gengæld uenighed mellem Proust og Grøndahl i forhold til erindringen. Et temmelig afgørende område. Proust tiltror på fiktionens præmisser ganske vist erindringen evnen som en sammenhængsskaben- 
de kraft, men det er frem for alt den ufrivillige, viljeløse erindring, Proust tildeler evnen til at kalde de forgangne år tilbage. Grøndahl skelner ikke så specifikt, men opfatter, ligesom digteren Klaus Høeck, erindringen som en upålidelig bevidsthedsinstans. Nok er erindringen forførende, men den viser sig for Grøndahl lige så ofte at være et bedrag, der skaber fiktioner i stedet for at fremkalde det, der var. Og dermed hindrer den, ligesom ordene, mennesket i at være fuldt og helt til stede i nuet og $i$ at se verden klart.

\section{Hvem er jeg?}

Prousts roman problematiserer og leger med læserens forventning til det skrevne jeg, det jeg, der møder os, når vi læser hans roman. Det proustske jeg er yderst sammensat, gjort af en lang række jeger, hvilket betyder, at vi aldrig kan vide os sikre på, hvem der taler på vegne af hvem og hvad. Det er umiddelbart en undflyende ubestemmelighed, der præger det proustske jeg, og som bestemmer vores forståelse af det. Det står aldrig hundrede procent til troende, hvem der er hvem. Og alligevel tror vi på det. Det er et jeg, der bliver til og skiftes ud og forsvinder i og med det skrevne. Det moderne jeg, der er og ikke er, genfinder vi hos Grøndahl, der også på dette punkt har suget næring fra og omsat arven fra Proust og Claude Simon til en fiktion, der drives af sted af skriftens egen bevægelse og de former for tilblivelser (jegtilsynekomster), den afstedkommer:

46 Jeg findes hverken i det skrevne eller det uskrevne, men i selve bevægelsen mellem tavshed og ord, en fortsat bevægelse, uafsluttet og uafsluttelig. Midtvejs mellem den, jeg ikke længere er, og den, jeg endnu ikke er blevet: dér skriver jeg. At skrive er i den forstand et forsøg på at nærme sig sin egen midte, kun for at opdage at midten er et åbent tomrum og en tom åbning mod universet: andre mennesker, fiktive som virkelige, romanpersoner som læsere. (Grøndahl 1998, 243)

Her beskrives jeget mere som et medie, som noget, der kommer og går, end som nogen vi nogensinde kan tage i hånden. Der er hos Grøndahl en betydelig bevidsthed om metafiktion indlejret i de sætninger, der møder os, som erkendelsesmæssigt ligger nær den, der kommer til udtryk hos Proust. Grøndahls og Prousts respektive betoning af erindringen og udforskning af skriften som et omfattende metareflekterende rum, der eksisterer side om side (med), og som en naturlig del af, det fortalte selv, medfører, at litteraturen ikke alene peger på sig selv som første og sidste mulighed for at fortælle. Sætningerne gør samtidig opmærksom på, at der ikke er noget andet end dem selv, mens de læses - og at der ikke er nogen til at binde det hele sammen. Selve det at skrive handler om at skabe mulighedsbetingelser for liv. Skriftens og eksistensens liv. Her fører Grøndahl ikke Proust så meget videre. Til gengæld medfører Grøndahls stilistiske greb, at man igen og igen, ligesom hos Proust, har at gøre med en skrift, der ikke kan leves, men som selv er katalysator for liv. Også på dette punkt har Grøndahl på eksemplarisk vis taget ved lære af sit franske forbillede og instrumentaliseret sin indsigt ud i essays og i roman efter roman. Der er hos Grøndahl ingen Harold Bloomsk angst for at være underlagt en anden 
forfatters indflydelse. Grøndahl tegner sig dermed som et mønstergyldigt eksempel på min Jauss-inspirerede receptionshistoriske triadeoptik. Grøndahl lader sig læse med mit triadegreb. Dermed menes, at han ikke blot som læser modtager og indoptager Proust. Han omsætter ham desuden i skrift og tænkende essayistik, efter at han været i skole hos Proust:

Proust hjalp mig, fordi alt, hvad jeg søgte ord for, allerede fandtes i hans undersøiske katedral. Han forudsagde min frigørelse, da han i et essay rådede den unge forfatter til at skrive pasticher. Først når man forsøger at skrive som en anden, og det mislykkes, kommer man frem til sin egen stemme. (Grøndahl 2010, 99)

Grøndahls forfatterskab kan samlet set frem til i dag, inklusive den seneste roman Jernporten (2014) med en proustsk tematik og fiktionsbevidsthed i sit dyb, læses som et signifikant bud på en reflekteret, stilbevidst dansk skønlitterær reception af Proust, samt på hvordan man som dansk forfatter på én gang kan skrive på og ved hjælp af indflydelsen fra Proust - og frigøre sig fra den. Det er på paradoksal vis af dén vej, Grøndahl har skabt sin helt egen stil. Grøndahls forfatterskab dementerer således påstanden og forestillingen om, at man er pisket til at gøre op med det, der udgør et forbillede for én som forfatter.

Det er netop i kraft af indflydelsen fra Proust, både i sin romanpraksis og essayistik, at Grøndahls stil skiller sig ud fra anden dansk litteratur som decideret udansk. Det synes nærmere bestemt at være Proust (samt Claude Simon), der for Grøndahl har sat standarden for, hvad man bør tilstræbe, og hvor langt man bør gå som skønlitterær forfatter, nu og til enhver tid. Det er på dette sted faktisk muligt at komme Grøndahls specifikke orientering nærmere og tilmed sætte ord på den. Nemlig den fænomenologiske tilgang, og den har Proust langt fra været alene om at skærpe hans blik for, slet ikke når vi samtidig tager i betragtning, at Grøndahls tidligste optagethed gjaldt filmmediet, det filmiske blik på verden. Men det er ikke forklaring nok. Måske er svaret Grøndahls tilgang til sproget selv. Den sproglige omgang med verden. Sproget og landskabet! Her kaster Grøndahl selv lys over sagen - og det grundlag, Proust m.fl. udgør for ham:

Man kan nemt fortabe sig i morfologiske associationer, men jeg er ikke i tvivl om, at sproget har modelleret min måde at tænke på, ligesom landskaberne har dannet mit blik. Lært mig at få øje på de små ting, de gradvise overgange, farveorgiet, hvis man bøjer sig ned på en klithede, der tilsyneladende er grå. Ikke desto mindre skulle der gå et halvt liv, før jeg mere uanstrengt kunne give mig hen til det, jeg alligevel ikke kan lave om på. Være mig selv? På en måde, ja, men ikke helt, for jeg går ikke restfrit op med landet, sproget og kulturen.

I mange år var det især franske forfattere, jeg følte mig knyttet til i et slægtskab, der forekom mig så meget mere personligt og sandt, fordi det var valgt: Flaubert, Proust, Simon, Duras, Modiano. De er indbyrdes meget forskellige, men har noget til fælles, som jeg tror er ret gallisk. En vis fænomenologisk tilgang, forankringen af det fortællende sprog i en oplevende bevidsthed, hvis nærvær ikke mindst kommer af dens afgrænsethed i forhold til en fremmed, uoverskuelig verden. (Grøndahl 2007, 101-2) 
Her understreges den fænomenologiske indstilling og tilgang, og her findes desuden en oplagt forklaring på, hvorfor Grøndahls forfatterskab er så værdsat i Frankrig (og andre europæiske lande), som tilfældet er. Der trives forfatterskabet som en ål i vandet blandt teoridannelser og læsemåder. Der er Grøndahl ikke underlagt den i Danmark ofte så fremherskende jantelovs-mentalitet, der har affødt både latterliggørelse og afstandtagen, holdt ved lige af en ofte ubearbejdet misundelse.

\section{Indflydelsen fra Proust-maskinen i dansk receptionsperspektiv}

I perioden 1940-47, krigens tid, blev Prousts roman næsten ikke omtalt. En grund kunne være, at man anså værket for at være for æstetisk verdensfjernt til, at man kunne bruge det til noget, blottet som det var for forbindelser til krigens nærvær. En anden grund kunne være, at 1940'erne i højere grad var lyrikkens, den eksistentielle kriselyriks årti. Både hvad denne og en senere kriseperiodes faldende interesse for Proust angår, er det værd at ihukomme sig Jacob Paludans forklaring på bølgebevægelserne i vurderingen af Prousts værk:

64 Værdsættelsen af Marcel Proust har sine bølgende Bevægelser: i svækkede Perioder, efter Krige, er Modtageligheden stor; naar saa moralsk Alvor bryder ind i Stemningen af Opløsning og Tvivl paa alting, kommer han paa de uønskedes Liste. Man jordfæster da for Tid og Evighed den dekadente - men ikke i Stilhed, for imens er han pludselig blevet opdaget af en ny Generation, der maa give Luft for sin Forbløffelse, som vi andre maatte. (Paludan 1949)

Paludans billede af bølgebevægelser i Proust-receptionen genkendes, så snart man dykker ned og fordyber sig nærmere i, hvordan det faktisk forholdt sig, da Proust kom på dansk, og hvad det i videste forstand har haft af betydning, ikke mindst for de danske forfattere. Bølgeanalogien korresponderer forbløffende med den periodisk stigende og faldende interessekurve, der kan spores helt frem til i dag. Af danske forfattere er Paludan vel den, der mest kontinuerligt har beskæftiget sig med Proust, hvad enten det er i form af essays, i anmeldelser af oversættelsen eller sekundærværker eller som åndelig næring til sine egne romaner.

I 1960'erne ændrede litteraturopfattelsen sig betragteligt som følge af den nævnte tematiske kritik med afsæt i Genéve-skolen. I tråd hermed og takket være Knud Togebys og især Niels Egebaks nøgternt og analytisk animerende formidling af bl.a. Georges Poulets, Jean-François Revels og Gilles Deleuzes skelsættende kritiske studier af På sporet, blev der kastet lys over Prousts værk som en modernistisk bevidsthedsroman. Blikket blev rettet mod teksten, der siden blev udsat for diverse strukturalistiske og hermeneutiske studier på bekostning af biografiske aspekter. Tendensen blev stærkt understøttet af den skrift-som-erkendelse-orienterede franske tematisk kritiske bølge, der fokuserede på romanen som et bevidsthedseksperiment, hvor den skabende handling forflyttes til læsningens akt. Dermed fik selve Prousts 'recherche' en helt anden erkendelsesmæssig betydning, hvilket den stensikkert også havde og fik for Proust selv, mens hans skrev. På dansk lyder det at være "på eftersøgning" temmelig detektivisk, men betoner samtidig lige præcis, at 
der er tale om en "undersøgende eftersøgning". Dér har vi efter min opfattelse den proustske indstilling, der er den drivende kraft i og for hans roman: På sporet af den tabte tid er en forskning i romanens form og selve grundlaget for at kunne skrive en roman, nærmere bestemt en praktiseret og praktiserende undersøgelse i og med skriften, og det vil her sige: det litterære udtryks hele mulighedsfelt. Proust er altså litteraturforsker på sin egen romanundersøgelses præmisser og de betingelser, han skrev ud fra. Dermed menes, at han sætter sin egen standard for, hvad en roman er og kan være.

Sideløbende med, at skriften betones som afgørende, bliver spørgsmålet om erindringens betydning for den sproglige praksis stadig mere relevant i forhold til Prousts roman. I 1970'erne var det derudover kun i anledning af Prousts 100 års dag i 1971, at der blev skrevet om Proust. Den udeblevne interesse for Proust i 1970'erne havde grund i, at tiåret var gennemsyret af krisestemning. Litteraturen blev generelt underlagt identifikatoriske, virkelighedstro og politisk-samfundskritiske kriterier. Set i dét perspektiv måtte Prousts værk unægtelig fremstå som både æstetisk, virkelighedsfjernt og snobbet med dets skildringer af det højere borgerskabs parisiske selskabsliv i slutningen af det forrige århundrede. Går vi til 1980'erne, slog en passioneret Jørgen Gustava Brandt vigtige slag for Proust som fuldkommen uomgængelig og skarpere end noget, der er skrevet på dansk. Første del af 1980'erne blev teoretisk domineret af interessen for æstetik og litterært af lyrikken. Først fra midtfirserne og frem blev der for alvor taget fat i Proust igen. Mogens Dupont-Petersen kom i 1985 med sit ligegyldige, anekdotiske essay, som Henrik Milton Sørensen kritiserede og gravlagde med et bredere sigte, der gik på at reaktualisere værket i retning af en genoversættelse, som vi nu endelig har fået. Bjørn Bredal meldte om frigivelsen af rettighederne til værket og præsenterede Proust på ny med Begærets by.

Ind i 1990'erne tog forfattere som Henrik Bjelke og Jens Christian Grøndahl over. I modsætning til Paludan, der så Proust som symbol på den tabte tid - den tid, hvor alt var mere ægte (kort sagt: tiden før Første Verdenskrig, og som mente, at Prousts søgen var et fors $\varnothing g$ på sekund for sekund at genskabe tiden som den var) ser både Egebak, Bjelke, Grøndahl og digteren Klaus Høeck erindringen hos Proust som en fiktionsgenererende problematiserende (og, i Høecks tilfælde, problematisk) kraft: De opfatter erindringen som del af den skabende, diktatoriske fantasi. Egebak får følgeskab af Bjelke og Grøndahl i bestræbelsen på at trække På sporet og Proust ind i nutiden som en evig aktuel og samtidig. Som tiden går, foretrækker man andre Proust-steder, end da man tidligere læste værket. Med tiden kommer der betydelig mere tyngde på, hvilket betyder, at man som læser i en ældre alder mere tager notits af de proustske lovmæssighedsbetragtninger, hvor almengyldigheden får fat i én. Det er synspunkter, som bl.a. Kirsten Thorup og undertegnede har givet udtryk for. Det betyder ikke, at detaljer, man førhen lod sig beruse af, har mistet deres betydning eller kraft, de bliver blot andre, der indgår nye forbindelser, der blander sig med éns læsning på et dybere plan.

Et udtalt gennemgående træk, man sporer i receptionen, er desuden, at de respektives tilgang til Proust er stærkt farvet af deres tids åndelige, kulturelle vejrlig og mere eller mindre udprægede teoridannelser. Fra Christian Rimestads til Kirsten Thorups tilgang til Proust sporer man ikke bare dybe litterære indsigter; man stifter 
tillige bekendtskab med såvel spirituelle som terapeutiske aspekter og potentialer, der direkte og indirekte afslører, hvad Proust gør ved os, og hvordan hans roman er i stand til at komme os til undsætning på planer og måder, vi ikke tidligere har oplevet.7 Kækt formuleret: Proust er ikke nogen terapeut, men hans tekst kan noget, vi ikke kan. Det betyder til gengæld ikke, at man blindt kan overtage hans synspunkter eller lovmæssige udsagn.

Siden har både Bredal, Jørgen Bruhn \& Bo Degn Rasmussen og Henning Goldbæk bidraget betydeligt til at skyde mangfoldige æstetiske, kunstteoretiske og litteraturvidenskabelige perspektiver ind i forståelsen og opfattelsen af Proust. Sporede man op mod årtusindskiftet en fornyet generel interesse dels for erindringsromanen som helhed og dels for den livsperspektiverende fortælling, var der, takket være især Goldbæks indsats - og herunder medregnes så sandelig også hans oversættelser af Benjamins Passageværket 1-2 (Rævens Sorte Bibliotek, 2007) og hans uvurderlige arbejder om Benjamin og Adorno - modgående tendenser i gang. Når det gælder Proust, er det ifølge Goldbæk særligt det fragmentariske, det foreløbige og flygtige, man bør indprente sig hos Proust. At man altså snarere bør opfatte værket som et symptom på det moderne, der indbefatter et syn på sproget som utilstrækkeligt, som ude af stand til at formidle og gabe over den virkelighed, vi lever i. Der er ifølge Goldbæk dog ikke tale om, at Proust forsøger at undslippe det moderne som følge af en sproglig afmagt, men at han, som Walter Benjamin gør rede for i sit essay "Til billedet af Proust" (1929), som Goldbæk henviser til, "påtager sig den uendelige opgave at se kunsten og kunstværket som fragmentarisk i forhold til kunstens idé" (Goldbæk 2002, 237, note 3). Det er selve årsagen til, at Benjamin omtaler Prousts roman som en "ukonstruerbar syntese". Den betragtning kan glimrende stilles i kontrast til H.P.E. Hansens langt tidligere forsøg på at præcisere Syntesen af Marcel Prousts værk (1929).

Litteraturreception handler ikke blot om at aflæse og påvise påvirkning og inspiration på et overordnet oversigtsplan. Den mere udfordrende og subtile del af den vedrører spørgsmålet om indflydelse, hvordan den sætter sig igennem, og hvorledes den forfatter, der skriver under indflydelse af - eksempelvis - Proust, forholder sig til samme i og med sit eget værk. Og modsat, hvordan læsningen af selvsamme danske værk, der forholder sig til det fremmede ditto (f.eks. Prousts), fornyer opfattelsen af selvsamme fremmede romanværk (På sporet af den tabte tid). Det er Jens Christians Grøndahls roman Skyggen i dit sted et signifikant eksempel på, ikke mindst ved intertekstuelt bevidst at skrive sig fri af Proust ved at skrive hans værk ind i sit eget og tilbagelægge det på sin egen fiktions betingelser. Skyggen i dit sted udgør, hvad Anna Balakian i sine indflydelsesstudier fra begyndelsen af 1960'erne kaldte "the turning point at which the writer frees himself of the influence and finds his originality" (Balakian 1962, 29). Som følge heraf kan vi sluttelig konstatere, at en internationalt værdsat dansk forfatter som Jens Christian Grøndahl ændrer og udfordrer vort syn på Proust og hans romanværk gennem konstant at insistere på litteraturens æstetiske gyldighed og den litterære erfaring inden for sin egen fiktions æstetiske praksis’ og essayistiks præmisser.

Forfattere som Kirsten Thorup og Josefine Klougart er andre markante eksempler på, hvordan man på produktivt frisættende vis kan betjene sig af Proust som en 
indflydelsesmaskine. I modsætning til de her nævnte forfattere melder den danske receptionshistorie om mange andre, der af den ene eller anden grund ikke har stået distancen gennem triaden eller været i stand til at frigøre sig fra Proust. Der skulle, som i Thorkild Hansens tilfælde, et opgør til, hvor han via anknytningen til en anden forfatter (André Gide) og en anden indstilling til skriften og verden, lagde afstand til den genstridige, yderst udfordrende og langtidsvirkende franskmands indsats.

Som moderne roman betragtet udgør På sporet én stor indflydelsesmaskine og litterær generator, som udvikler andre typer af skrift hos mange af de forfattere, der giver sig i kast med værket. I sammenhæng dermed fremstår romanen i tråd med Deleuzes opfattelse som en maskine, der producerer sandheder. Den udgør ikke blot én, men flere forskellige maskiner, som repræsenterer forskellige slags sandhedsproducenter (Deleuze 2003, 164-65). Men med de nævnte danske forfatteres relation til Proust og På sporet in mente bør romanmaskine-metaforen opfattes i bredeste betydning og bestemt ikke kun anskues udfra en deleuziansk optik.

\section{Afrunding}

Vi har i dag med enhver tænkelig og utænkelig slags Proust at gøre til trods for, at det fortsat er de allerfærreste, der har læst hans værk. Pointen med den nedenstående liste er at pege på, at hver enkelts forhold til Proust rummer atter andre slags Prouster. Der spiller selve værkets polyfone indretning i betydelig grad ind på læserens eget behov for at differentiere mellem den ene, anden og tredje Proust, hvad enten vi har at gøre med fortælleren, protagonisten, forfatteren eller tekstens egen måde at udtrykke Proust bagom "Proust" på. Listen er uden ende: Rimestad har sin Proust, Paludan har sin Proust, Barthes har sin Proust, Blanchot har sin Proust, Benjamin har sin Proust, Cees Noteboom har sin Proust, Woolf har sin Proust, Espedal har sin Proust, Knausgård har sin Proust, Ekelöf har sin Proust, Kirsten Thorup har sin Proust, Prinsgemalen, prins Henrik har sin Proust, Jørgen Bruhn har sin Proust. Peer Hultberg har sin Proust, Goldbæk har sin Proust. Jeg har min Proust. Du får din Proust.

\section{Noter}

I Se Conrad Thing 2013.

2 Samtlige behandles og perspektiveres i min kommende ph.d.-afhandling I dialog med Proust. Den danske Proustreception gennem hundrede år, forventet disputation 19. September 2015, Lunds Universitet.

3 Læs nærmere om Thorkild Hansens relation til Proust i Conrad Thing 2013, 154-193.

4 'Nye litterære' vil her sige: værker, som ikke er oversættelser af den influerende forfatters værk.

5 Carsten Jensen skriver: "Det fælles element, hvori vi bevæger os omkring mellem hinanden, er mørket og tavsheden, og i det er vi skjult. Vi er kun appendikser til situationerne, for altid tabte i hinandens glemsel. Stederne er der, og i dem, i den rumlige eksistens, ligger kontinuiteten, ikke i os.", i (Jensen, 1991, 6).

6 Jf. Grøndahl 1991, 55 og 84. Samme citat leger Grøndahl med i artiklen "Den, der siger Jeg”, Weekendavisen. Bøger, 20.-26. september, 1991. 
7 Under mine egne Proust-læsninger har jeg opdaget terapeutiske aspekter, der er forbundet med romanens yderst nuancerige og flerstemmige sproglige udformning. Det indebærer ikke blot, at man selv får et større sprog af at læse Proust; man opdager tillige muligheder for at komme sig selv til undsætning.

\section{Litteratur}

Balakian, Anna (1962): "Influence and Literary Fortune: The Equivocal Junction of two Methods", i YCGL XI: 24-31.

Conrad Thing, Neal Ashley (2013): Proust i Danmark. 1913-2013, København: Multivers. Deleuze, Gilles (2003): Proust og tegnene, Frederiksberg: Det lille Forlag.

Egebak, Niels (1967): Indskrifter. Essays om fænomenologi og æstetik, Arena: Fredensborg.

Goldbæk, Henning (2002): Marcel Proust og barokkens genkomst, Hellerup: Forlaget Spring.

Grøndahl, Jens Christian (1991): Skyggen i dit sted, København: Gyldendal.

Grøndahl, Jens Christian (1998): Night Mail, København: Munksgaard.

Grøndahl, Jens Christian (2007): Tre skridt tilbage, København: Gyldendal.

Grøndahl, Jens Christian (2010): Om en time springer træerne ud, København: Politikens Forlag.

Grøndahl, Jens Christian (2013): Den sibiriske måne, København: Gyldendal.

Hansen, H.P.E. (1929): Syntesen af Marcel Proust værk: Essay, København: Hagerup.

Høeck, Klaus (2012): “og måske skal sjælens genopstandelse opfattes som et hukommelses-fænomen”, i Ind i Prousts værk - 19 læsninger i 'På sporet af den tabte tid', s. 112-115. København: Det danske Proust-selskab.

Jauss, Hans Robert (1992): "Konsternas historia och historieskrivningen," oversat af Horace Engdahl, i Modern litteraturteori. Från rysk formalism till dekonstruktion Del 1, s. 364-396, Lund: Studentlitteratur.

Jensen, Carsten (1991): Af en astmatisk kritikers bekendelser, København: Gyldendal.

Paludan, Jacob (1949): “Skribenter paa Yderposter”, Redegørelser og Debatter, København: Steen Hasselbalchs Forlag.

Proust, Marcel (1964-65): På sporet efter den tabte tid, 7 bd., København: Martin Forlag.

Proust, Marcel (2002-2014): På sport af den tabte tid, 13 bd., København: Multivers.

Robbe-Grillet, Alain (1965): På vej mod en ny roman, Fredensborg: Arena. 